\title{
Estrategias y representaciones en tiempos de censura: los casos de La Opinión (Argentina) y Opinião (Brasil) ${ }^{1}$
}

\section{Marina Poggi}

Doctora; Universidad Nacional de Quilmes marinapoggicarter@gmail.com

\section{Resumen}

La "prensa de análisis" se consolida en Latinoamérica en la década del '70 con el periódico La Opinión (Argentina, 1971) y el semanario Opinião (Brasil, 1972) en un contexto de libertad de expresión restringida. La novedad eran las columnas firmadas, la ausencia de espacio editorial, que otorgaba un espacio prioritario al análisis de unos pocos temas antes que a brindar información variada de la actualidad y que se dirigía a minorías con intereses particulares. El sello distintivo que caracterizó a ambos medios radicaba en la utilización de la caricatura y la composición de imágenes con sentido irónico como estrategia para expresar lo que no era posible poner en texto. Contemplando tales similitudes, la propuesta es estudiar el desempeño de la prensa en su rol de actor político en los albores de una etapa de censura que dejará huella en la historia de la democracia latinoamericana.

\section{Palabras clave}

Prensa de Análisis. Representaciones. Discursos.

\section{Introducción}

La prensa de análisis, definida como periodismo de interpretación o explicación a partir del estilo consagrado por el semanario norteamericano Times, en Argentina se instaló en las revistas de actualidad de la década del '60 de la mano de Jacobo Timmerman, con la

\footnotetext{
${ }^{1}$ La versión completa de este trabajo corresponde a la tesis Posdoctoral defendida en el contexto del Posdoctorado en Comunicación, Medios y Cultura: “Comunicación, Poder y Derechos Humanos”, Universidad Nacional de La Plata - Facultad de Periodismo y Comunicación Social - Cohorte 2013.
} 
revista Primera Plana lanzada en 1962 y Confirmado en 1965 (ROST, 2003). Este estilo se consolidó en Latinoamérica en los inicios de la década siguiente con el surgimiento en Argentina en 1971 del periódico La Opinión y en Brasil en 1972 del semanario Opinião, en un contexto de censura que respondía a experiencias de gobiernos militares.

Como rasgos novedosos, esta prensa incorporó las columnas firmadas, estaba desprovista de espacio editorial y había sido concebida para ser leída por minorías con intereses particulares (intelectuales, estudiantes universitarios y militantes de izquierda), otorgándole un lugar prioritario al análisis de unos pocos temas antes que a brindar información variada de la actualidad, es decir que daba prioridad al análisis y al debate intelectual antes que a la información. Así, el nuevo género combinó la dinámica de Times con la estética de Le Monde, pretendiendo un estilo que los asociara principalmente con la seriedad y el prestigio del diario francés. Además de dicha condición diferencial en el tratamiento de las noticias, el sello distintivo que caracterizó a ambos medios radicaba en la utilización de la caricatura y la composición de imágenes con sentido irónico como estrategia para representar lo censurado, para expresar lo que no era posible poner en texto.

La conformación análoga de La Opinión y Opinião incluía ilustraciones y caricaturas en vez de fotografías, con las que estas publicaciones procuraron imprimir una diferencia en el tratamiento de la información respecto de la prensa tradicional que circulaba en el período. De esta manera, la elección de los dos medios responde a las posibilidades comparativas, tanto en su estética copiada de Le Monde, como en contenidos y en el público lector al que se dirigen. Pero también porque ambos nacen, con un año de diferencia, en contextos políticos conflictivos y finalizan en el mismo año (1977) bajo los efectos de la censura y la clausura de las instalaciones por la acción de gobiernos autoritarios. La elaboración de sus discursos y la posible influencia de ellos en las decisiones políticas, son aspectos que merecen ser estudiados, contemplando que marcaron el inicio de una nueva prensa crítica y de análisis, un formato que fue innovador para el estilo tradicional de la prensa gráfica de sus respectivos países.

Contemplando las similitudes descriptas, la propuesta es abordar tres ejes analíticos y comparativos en función de estudiar el desempeño de la prensa en su rol de actor político. 
El primero parte del cuestionamiento: ¿Qué dice Le Monde acerca de Argentina y de Brasil? Resulta interesante analizar las representaciones construidas por el medio francés sobre estos países, ya que ambos estaban experimentando transformaciones tanto sociales como políticas que exigían un cambio en las formas de circulación de la información. En segundo lugar, el análisis estuvo centrado en uno de los aspectos que determinó la trascendencia de ambos medios, que fue la caricatura como medio de expresión y estrategia para sortear los límites impuestos por la censura. Se analizó el rol político que adopta cada medio frente a coyunturas, aunque diversas, conflictivas y signadas por la represión. Con el objetivo de puntualizar el análisis en el comportamiento de un tópico en particular, el tercer eje estuvo focalizado en la representación del accionar político de estos medios frente a una temática que estaba llamando la atención a nivel mundial: la cuestión de la propiedad de la tierra. Este eje pretendió constituirse en material empírico que dé cuenta no sólo de "que dice" la prensa en relación a una determinada temática, sino fundamentalmente en "como lo dice". De este modo, se abordó el estudio comparativo de dos medios de prensa desde tres perspectivas distintas, pero que en conjunto permiten conformar una vista panorámica tanto del objetivo como del accionar concreto de una prensa que fue tan intensa como efímera.

En cuanto al marco teórico metodológico, está ubicado en las teorías de las representaciones y los discursos sociales. Por representaciones se entiende el uso lingüístico desnaturalizado (RAITER; ZULLO, 2008), es decir, un uso intencional que muestra algunas cosas y oculta otras, y se pregunta el por qué y el para qué de estas operaciones. Los interrogantes que articulan este aspecto giran en torno a develar los elementos que construyen el poder de representación en la prensa y de qué modo ese poder es legitimado. Luego, el discurso social se concibe no como general ni como individual, sino en la cacofonía coyuntural que lo ubica como hecho social y, a partir de allí, como hecho histórico. Ello pensado en una trama de intertextualidad, llena de "ecos y de recuerdos", penetrada por tendencias, teorías y visiones de una época (ANGENOT, 2010, p. 25).

Estas perspectivas también serán contempladas para abordar el uso de la imagen y la caricatura como medio de expresión de lo "indecible" (ANGENOT, 2010), en donde la imagen se considera como unidad significante no homogénea que contiene a la vez marcas lingüísticas y marcas no lingüísticas (VERÓN, 2004). 
En cuanto a lo específicamente metodológico, se recurre a las categorías propuestas por el Análisis Crítico del Discurso (ACD), que estudia el lenguaje como práctica social, es decir, como una forma de significar a un particular ámbito de la práctica social desde una particular perspectiva, y considera que el contexto del uso del lenguaje es crucial (WODAK, 2003). Para el ACD “[...] las estructuras dominantes estabilizan las convenciones y las convierten en algo natural, es decir, los efectos del poder y de la ideología en la producción de sentido quedan oscurecidos y adquieren formas estables y naturales." (WODAK, 2003, p. 1920).

Por último, para estudiar el escenario de la prensa, se utilizó la metáfora de la "escena enunciativa" (FONTE, 2003), que refiere al despliegue de voces que conforman la dimensión política de un acontecimiento en la prensa. Se abordaron los actores principales colocados en escena mediante la caricatura, puestos en relación con el evento que los hace protagonistas.

\section{La vanguardia como premisa}

En tanto, posibilidades comparativas de dos sociedades, historias y Estados distintos que atravesaban caminos contrarios aunque en un mismo momento cronológico ${ }^{2}$, los medios del Conosur analizados significaron un punto de encuentro en cuanto a la necesidad y a la búsqueda de un cambio en el estilo periodístico. De este modo, Times representaba el giro dramático necesario en cuanto al tratamiento de las noticias, mientras que Le Monde era el modelo a seguir, la vanguardia de la independencia periodística que los inspiraba.

Le Monde fue creado en 1944 por Hubert Beuve-Méry³, con el objetivo de instaurar una prensa libre, nacional e independiente ${ }^{4}$. El diario obtuvo rápidamente un profuso prestigio y se convirtió en un referente de la prensa internacional. Hacia 1971 era dirigido por el periodista y escritor Jacques Fauvet. Mantenía el formato berlinés de origen, y el número de

\footnotetext{
2 Argentina se encontraba en una incipiente democracia que promovía discursos de renovada libertad de expresión, pero que en los hechos políticos construía espacios de violencia que la encaminaron rumbo a una dictadura militar. Brasil estaba debilitado políticamente y la sociedad buscaba el camino hacia la salida democrática, pero con un recrudecimiento de las prácticas de censura.

${ }^{3}$ Tras la liberación de Francia, Hubert Beuve-Méry monta el diario sobre lo que quedaba de las instalaciones de Le Temps, donde anteriormente trabajaba y renunció por su postura poco crítica ante el accionar de Adolf Hitler.

${ }^{4}$ También consultar: EVENO P. Le journal Le Monde: une histoire d’ indépendance. París: Odile Jacob, 2001. y PAZ REBOLLO, M. El periodismo en Francia. En: PIZARROSO QUINTERO, A., Historia de la prensa. España: Centro de Estudios Ramón Areces, 1994.
} 
páginas oscilaba entre veintidós y cuarenta y dos, sin una constancia observable en relación al día o a las secciones. Entre otras de las características editoriales destacables, cabe mencionar que algunas notas de opinión se encontraban firmadas, rasgo que incorporarán como novedoso tanto La Opinión como Opinião. Tenía una abundante cantidad de secciones que abarcaban una multiplicidad de áreas de cobertura (arte, ciencia, medicina, tecnología, religión, entre otras tantas). A la vez, estas secciones se acomodaban en subsecciones de noticias, definidas por la demanda informativa, rasgo que será adoptado por La Opinión. Contaba con abundante pauta publicitaria, y suplementos que salían esporádicamente. Poseía muy escasa fotografía, pero pueden hallarse durante los `70 algunas caricaturas en el interior, aunque no en la tapa y siempre asociadas a la cuestión política francesa. También contaba con una versión semanal inglesa (Weekly English Editions), que se trataba de un espacio de información condensada.

El semanario Times fue el producto de la unión de Henry Luce y Briton Hadden, dos universitarios de Yale, que lanzan en 1923 este medio como expresión de un nuevo periodismo. Estaba pensado para un lector ocupado que no había tenido tiempo de leer todos los diarios, todos los días de la semana, y por lo tanto requería de una visión en conjunto y que en lo posible le aportara un anticipo de lo que acontecería luego. El objetivo era romper con la idea del relato objetivo de los hechos, porque la periodicidad semanal debía ofrecer alguna alternativa que resulte complementaria a la información diaria: la fórmula del éxito estaba basada en el concepto de servicio profesional. Las noticias adquirían una nueva dimensión, ya que además de ser explicadas eran puestas en contexto. Este concepto, que se había aplicado inicialmente a lo semanal, rápidamente se extendió como parte de lo que se conoció como el timestyle y comenzó a ser empleado por la prensa diaria 5 .

Sobre estos modelos editoriales, pero fundamentalmente a partir del prestigio adquirido por Le Monde durante casi tres décadas, es que La Opinión y Opinião articulan su empresa, con el propósito de convertirse en una prensa distintiva y de reputación.

La Opinión fue creado el 4 de mayo 1971 por el periodista Jacobo Timerman en un contexto político nacional conflictivo y cambiante, pero propicio culturalmente para lanzar un

\footnotetext{
5 Para ampliar: FAGOAGA, C. Periodismo interpretativo: el análisis de la noticia. Barcelona: Mitre, 1982. y SANTIBÁÑEZ MARTINEZ, A. Periodismo interpretativo o periodismo de opinión: un intento de clarificación. Medios y Comunicación, Chile, n. 5, 1985.
} 
diario a la altura del medio francés, que no tan solo fue inspiración sino que, literalmente, fue tomado como modelo estético (RUIZ, 2001). La característica principal era la información con análisis y daba un lugar central al juicio de los periodistas. Era un proyecto de 24 páginas y formato tabloide que no intentaba competir con otros medios en cuanto a cantidad de información, sino que se ocupaba de pocos temas pero en profundidad y con una mirada universal. Estaba pensado -a diferencia de Le Monde, pero siguiendo el estilo de Times-, como un complemento de la información general que ofrecía la prensa tradicional. Otra característica tomada del diario francés era que no salía los lunes para evitar así la cobertura deportiva del domingo. El sello distintivo lo imprimió la caricatura, obra del artista plástico Hermenegildo Sábat, que reemplazaba la fotografía y sorteaba los límites impuestos por la incipiente censura: el objetivo era mostrar aquello que no se podía textualizar tan crudamente como se pretendía.

Timerman fundó y dirigió la publicación. Además de Sabát en las ilustraciones y caricaturas, contó entre sus filas con Horacio Verbitsky como jefe de redacción, Juan Carlos Algarañáz en política nacional y Jorge Riaboi, Arcadio Oña y Luis Felipe Sapag en economía. Entre otras figuras destacadas, participaron Juan Gelman y Miguel Bonasso, quién ingresó para cubrir de forma exclusiva la llegada de Héctor Cámpora al poder (MOCHKOFSKY, 2004). En su mayoría, los integrantes de La Opinión coincidían ideológicamente con la militancia peronista o de izquierda. Por ejemplo, Verbitsky, Sapag y Bonasso militaron en la organización guerrillera peronista Montoneros. Algañaráz simpatizaban con la izquierda peronista y Gelman se unió a las Fuerzas Armadas Revolucionarias (FAR). El proyecto original de La Opinión llegó a su fin el 25 de mayo de 1977, cuando su director y fundador fue secuestrado, y el diario clausurado y expropiado por el gobierno militar. Sin embargo, la intervención militar le dio continuidad de publicación hasta 1981, pero bajo una línea editorial modificada (RUIZ, 2001). ${ }^{6}$

Por su parte, el semanario Opinião fue lanzado en Río de Janeiro el 23 de octubre de 1972 en pleno régimen dictatorial que imponía la censura de prensa, con el general Emilio

\footnotetext{
${ }^{6}$ Ruiz (2001, p. 447) explica que “[...] la primera edición del diario bajo la intervención fue la del miércoles 25 de mayo de 1977, y en ella se publicó el histórico discurso de Jimmy Carter, en la Universidad de Notre Dame, sobre los derechos humanos en el mundo. La frase más resonante de ese discurso fue: 'Las palabras son acciones'. No había mejores palabras para expresar la vocación histórica de La Opinión, un diario que ese mismo día, en el sur de América, había dejado de ser lo que era.”.
} 
Garrastazu Médici en el poder. Ese día fue publicada la edición experimental № 0 que constó de solo cuatro páginas. El semanario, cuyo contenido estaba centrado en la política y la cultura, nace de la fusión del proyecto editorial de Fernando Gasparian -empresario vinculado al gobierno de João Goulart, integrante del "grupo nacionalista", intelectual y defensor de la democracia -y de Raimundo Rodrigues Pereira, periodista de la exitosa revista Realidade. A partir del № 1, publicado el 6 de noviembre de 1972, el semanario se estabilizó en 24 páginas y así continuo hasta su cierre en abril de 1977.

Opinião, que surge como espacio contestatario hacia el gobierno militar, contó entre los colaboradores más conocidos con el sociólogo Fernando Henrique Cardoso (quién luego fue presidente), el escritor mexicano Octavio Paz y el sociólogo francés Alain Touraine (FERNANDO..., 2006). El semanario intentaba “[...] ampliar los límites de las libertades públicas [...]", y en La Opinión fue anunciado como "[...] un semanario que aparece como edición brasileña del periódico francés Le Monde [...]” (RUIZ, 2001, p. 48). Era el propio semanario el que se presentaba como una edición brasileña de Le Monde, a la vez que publicaba una selección de artículos de diversos diarios y revistas: The Washinton Post, The Guardian, The New York Review of Books y New Statesman. En su edición experimental, Opinião se publicitaba como:

[...] um jornal que não defende interesses pessoais, não pertence a nenhum partido, não é porta-voz de qualquer ideologia e se recusa a aceitar um volume de publicidade que ultrapasse a 20 por cento de sua receita. Esses são os princípios básicos de OPINIÃO. (OPINIÃO, 1972-1977).

También utilizó la ilustración y la caricatura como característica distintiva y contó con varios dibujantes que alternaban sus obras, las cuales aparecieron en todas las tapas de su existencia. Entre los artistas más destacados cabe mencionar a Elifas Andreato (responsable del equipo de ilustradores), Luis Trimano (artista plástico argentino que emigró hacia Brasil en 1968 y reside en Río de Janeiro desde 1974) y Cássio Loredano.

A su modo, cada uno de los medios descriptos nació y se desarrolló con la intención de ser vanguardia en cuanto al estilo periodístico. Contemplando las diferentes coyunturas en las que se desenvolvieron, estos medios introdujeron un nuevo modo de pensar la relación entre la producción de la información y sus receptores. 


\section{El mundo en protesta}

Entre las décadas de 1960 y 1970, se perciben transformaciones en la economía del mundo capitalista que advertían el inicio de un período de crisis. Los problemas manifestados en el plano productivo fueron los causantes de la ruptura de la "[...] edad de oro del capitalismo [...]" (RAPOPORT, 2005, p. 505). La escena mundial estaba plagada de protestas desencadenadas por el Mayo Francés y las movilizaciones contra la Guerra de Vietnam en los EE.UU., con el condimento de la amenaza del avance del comunismo debido al triunfo de la revolución cubana a principios de 1959 y los coletazos de la Guerra Fría.

Por otra parte, la población europea en general ya desde el inicio de la década de 1960 sufría modificaciones, las que impactaron directamente en el modo de vida y de trabajo. Por ejemplo, los pobladores rurales se encontraban en descenso, por lo que el campo se iba vaciando al tiempo que las ciudades se llenaban: el mundo de la segunda mitad del siglo XX se urbanizó como nunca (HOBSBAWN, 1998), dando inicio a un fenómeno de explosión urbana (BRIGSS, 1972). En este contexto Francia, junto a Alemania, aparecían desde fines de la segunda guerra mundial como las claves del poder económico en Europa (BRIGSS; CLAVIN, 1997).

En Francia, el hecho destacado de fines de la década de 1960 ocurrió en mayo de 1968, y se trató del levantamiento estudiantil del que París fue el epicentro, y que precipitó una ola de huelgas, a nivel mundial, de obreros en demanda de mejores salarios y condiciones laborales. Sus repercusiones se prolongaron en 1969 y 1970. Esta rebelión estudiantil -que en la historia ha quedado registrada como el "Mayo francés" - tuvo lugar en un ambiente de crisis y fue seguida de una serie de graves huelgas contra las cuales el Gobierno se mostró impotente. Antes que dirimir, el presidente francés Charles De Gaulle anunció que la Cámara sería disuelta. Sin embargo, una primera impresión de que De Gaulle saldría fortalecido de esta crisis cambia drásticamente y el gobierno de la Unión por la Nueva República (UNR), iniciado en 1958, hacia 1968 ya daba evidencias de su declive. Su renuncia fue el 28 de abril de 1969 (JOHNSON, 1972).

La década de 1970 en Francia inició con vientos de cambio y la dimisión de De Gaulle fue una señal de ello (BRIGSS; CLAVIN, 1997). La nueva presidencia estuvo ocupada interinamente por Alain Poher, del Movimiento Republicano Popular (MRP), y luego por 
Georges Pompidou (UNR) hasta abril de 1974. Las proclamas y exigencias de cambios, ecos del "Mayo francés", redefinieron el concepto de libertad. Comenzaron a configurarse nuevas costumbres y modos de vida: “La liberación personal y la liberación social iban, pues, de la mano, y las formas más evidentes de romper las ataduras del poder, las leyes y las normas del estado, de los padres y de los vecinos eran el sexo y las drogas." (HOBSBAWN, 1998, p. 334) sumados a la ampliación de los límites del comportamiento públicamente aceptable. En este contexto de agitación mundial, las dictaduras en el Cono Sur de América no actuaron de manera aislada, sino que fueron pensadas como una estrategia conjunta de terrorismo organizado y progresivo, cuyo argumento y objetivo estaba fundamentado en reprimir a una amenazante subversión que se infiltraba en todos los niveles de la vida nacional (RAFFIN, 2006).

En Argentina, el régimen militar iniciado en 1966 -autodenominado Revolución Argentina- había instalado el modelo llamado Estado Burocrático Autoritario. El golpe fue promovido por la Junta de Comandantes de las Fuerzas Armadas, la que designó como presidente al general Juan Carlos Onganía. El perfil ideológico del gobierno era antiliberal en lo político y liberal en lo económico. Onganía acentuó el autoritarismo promulgando diversas leyes de corte represivo, interviniendo los medios de comunicación y restringiendo la libertad de prensa. Tres años después de su inicio, este gobierno alcanzó su punto máximo de deterioro y las protestas sociales comenzaron a multiplicarse, insertas además en el contexto mundial de demandas antes mencionado. El gran estallido social tuvo lugar en Córdoba el 29 de mayo de 1969 y fue conocido como “El Cordobazo” (RAPOPORT, 2005).

Los '70 iniciaron con el Gral. Levingston en el poder y con el comienzo del accionar de la guerrilla, cuyo funcionamiento perduró hasta el golpe militar de 1976. Fue reemplazado en 1971 por el jefe del Ejército, Alejandro Lanusse, quién era consciente de que no se podía gobernar sin la legitimidad y el consenso de las masas populares: restableció las actividades de los partidos políticos y anunció un próximo acto de elecciones populares. Ante la evidencia del agotamiento de la "Revolución Argentina", y en vistas de que la impopularidad militar crecía y la agitación contra el régimen era generalizada, propuso un convenio denominado el Gran Acuerdo Nacional que daba paso a la restitución de la democracia, pero con un control militar. Juan Domingo Perón -ex presidente argentino exiliado hasta 1974 en España y líder 
de la fuerza política llamada peronismo -dio su negativa al acuerdo. En este contexto, las guerrillas adquirieron mayor espectacularidad, las manifestaciones de protesta de sectores medios y obreros se multiplicaron, y la represión y los procedimientos ilegales se intensificaron. Frente a un escenario de caos y descontento popular, Perón apareció como la única alternativa viable para recuperar la tranquilidad social y fue apoyado por sectores diversos y antagónicos.

En su primer regreso al país el 17 de noviembre de 1972, luego de 17 años de exilio, Perón organizó el Frente Justicialista de Liberación Nacional (FREJULI), constituido por el peronismo, el desarrollismo, la democracia cristiana, el conservadurismo popular, desprendimientos del socialismo y del radicalismo y algunos partidos provinciales, como una manifestación política del apoyo policlasista. Para dirimir los conflictos existentes dentro del propio movimiento, regresaba dispuesto a retomar el viejo peronismo, aunque el marco estructural ya era muy diferente.

Por su parte, el panorama brasileño era complejo dado el violento régimen militar en el poder desde 1964 -primer golpe militar del Cono Sur- que termina con el proyecto populista de João Goulart. El objetivo inicial era radicalizar el mando de las fuerzas armadas, y para ello “[...] se generó una cultura del miedo y una pérdida de lazos sociales cuyas consecuencias principales fueron la hiperpolitización de la cúpula y la despolitización de las bases de la sociedad." (RAFFIN, 2006, p. 135). La figura presidencial, ocupada Emilio Garrastazu Médici desde el 30 de octubre de 1969, era débil y poco confiable. Su presidencia llegó en un momento de crisis y desgaste de la imagen militar que tomó al miedo como el recurso más eficaz y su impopularidad fue aumentando gradualmente (IGLÉSIAS, 1994). Durante algunos años Brasil apareció frente a la opinión pública mundial como uno de los casos más escandalosos de violaciones a los derechos humanos, pero tristemente sería apenas el preludio de un ciclo oscuro en el sur del continente (RAFFIN, 2006).

Hacia finales de 1969 se creó en São Paulo la Operação Bandeirantes (OBAN) en la cual se asociaron el Estado y el ejército. También se multiplicaron los organismos de información como el Departamento de Operaciones e Información - Centro de Operaciones y Defensa Interna (DOI-CODI) que funcionaron primero en São Paulo y luego en otros estados (IGLÉSIAS, 1994). En el mismo período, se dieron huelgas masivas en São Paulo, cuyo 
resultado fue la formación de la Central Única de los Trabajadores (CUT) y del Partido de los Trabajadores (PT) (BETHELL, 1997).

A pesar de la compleja situación política, el momento financiero se vio favorecido debido a que se había eliminado la fiscalización del Congreso y los militares tenían manos libres por no tener que rendir cuentas ni defender programas. Fue mejorado el ingreso del capital extranjero y se hizo más viva la presencia de las multinacionales, propiciando la modernización. Las consecuencias fueron padecidas por la Naturaleza en obras y proyectos, como la explotación de minas y yacimientos y la construcción de rutas (IGLÉSIAS, 1994). Estas innovaciones socioeconómicas, realizadas vía un capitalismo desigual que favorecía a los sectores oligárquicos, despojaron a los más desfavorecidos y acentuaron la miseria, elevaron la inflación, la recesión y la deuda externa (RAFFíN, 2006).

En este paisaje relatado, atravesado por el calor de la protesta y la crisis social, nació y se desarrolló la prensa de análisis en Latinoamérica. Prensa que miraba a una sociedad francesa también cruzada por un clima de levantamiento popular.

\section{Opiniones en el mundo}

Si bien tanto La Opinión como Opinião tomaban como una de sus mayores influencias al diario francés, Le Monde no daba cuenta de tal acontecimiento. El nacimiento de los medios latinoamericanos no fue siquiera mencionado en los meses de sus respectivas fundaciones y la información que publicaban tampoco se manifestaba como proveniente de ellas. De hecho, las noticias de Le Monde provenían de agencias o de corresponsales, y en algunos casos de otros medios locales. Sin embargo, es interesante preguntarse cuál era la mirada del diario francés hacia Argentina y Brasil, qué representaciones construyó acerca de estos dos países.

En tanto en Argentina nacía La Opinión, Le Monde no registraba tal acontecimiento. Pero si ofrecía cobertura acerca de los movimientos no solo de la agitada política Argentina, sino que también incluía información acerca de costumbres sociales. Durante mayo de 1971 se publicaron un total de cuatro noticias y en junio ascendieron a siete. Si bien algunas provenían de agencias como Reuter y AFP, las de contenido analítico profundo acerca de la situación argentina llegaban a Le Monde por medio de Philippe Labreveux, su corresponsal en Buenos Aires. 
En tiempos en que los principales acontecimientos en Argentina giraban en torno al regreso de Perón a su país de origen tras su largo exilio en Madrid, y las circunstancias en las que se llevaría a cabo, Le Monde tomó nota de los acontecimientos y se ocupó de relatar pormenores de las negociaciones para propiciar el retorno, las que demoraron mucho más de lo esperado. De este modo, durante mayo desentrañó el derrotero de las idas y vueltas para dar fin del exilio de Perón, de las largas filas de visitante a Puerta de Hierro, y advierte tempranamente que la clave del impedimento residía en el propio peso de "l'ancien président" y su importancia significativa en la política argentina. En este mismo sentido, la dirigencia política argentina y el accionar sindical también se encontraba en el centro de la información.

Una información sobre la que Le Monde se detiene también es sobre la cuestión cultural del consumo carne, y sostiene que una de cada dos semanas el argentino se ve privado de su bife o de su tradicional asado, motivo de medidas estatales condicionadas por la exportación y por el intento de subir el precio del producto. El diario destaca que la terminología del asado convive cotidianamente con el lenguaje de los "incorregibles carnívoros que son los argentinos" y bromea con la fantasía de que un asado de los mencionados puede seducir hasta al más duro de los vegetarianos. Otro tema que ocupa la información durante varios días de mayo y junio es el secuestro por parte de la Ejército Revolucionario del Pueblo (ERP) del cónsul honorario de Gran Bretaña en Rosario, Mr. Stanley Sylvester, quien quedó temporalmente a disposición del curso de la justicia popular. Finalmente, el $1^{\circ}$ de julio Le Monde advierte que Sylverster ha sido liberado el 30 de mayo, luego de una semana de captura en la "prisión del pueblo", dando cierre a esta historia.

Durante julio, las novedades estuvieron centradas en los cambios de gabinete y en el anuncio de que el gobierno permitiría a los partidos políticos ejercer libremente sus actividades a partir del $1^{\circ}$ del mes siguiente, información que se mantuvo actualizada durante todo el mes. Sin embargo, la guerrilla y la convulsión social no abandonaron la estelaridad en esos días: el ataque violento en un pequeño pueblo de en Santa Fe - el cual incluyó el robo a un banco y el ataque a una central telefónica, la protesta de profesores por reivindicaciones salariales y su oposición al gobierno militar, fueron las noticias que predominaron en escena. 
También retrataba la amenaza de intervención militar sobre el gobierno en curso que permanecía latente. Pero el tema central fue la reunión mantenida en Madrid por Perón con el secretario general de la Confederación General de Trabajadores José Rucci y el secretario del movimiento justicialista Jorge Paladino, destinada a evaluar el progreso de las negociaciones entre los peronistas y el gobierno de Lanusse, con miras a conseguir la restitución del pasaporte argentino de Perón, cuestión que pondría fin a su condición de exiliado.

La presencia de Brasil en Le Monde fue en cambio significativamente menor: en mayo aparece una sola noticia que alude al país y en junio asciende a seis. La temática central abordada apuntaba a las políticas adoptadas por el cuestionado régimen dictatorial, el despegue industrial y las relaciones diplomáticas que lo colocan como líder en el sur del continente. Un caso registrado fue la negativa a liberar a tres religiosas dominicanas, arrestadas por realizar actos subversivos. Otro, la renuncia de Carlos Lamarca a la dirección de la Vanguardia Popular Revolucionaria (VPR). También, la denuncia por parte de obispos de la existencia de la organización terrorista "escuadrones de la muerte", y la escandalosa impunidad de la que disfrutaban, y la fuga de 245 detenidos de una penitenciaría de Bahía. Luego, el acuerdo con Francia para navegar en aguas territoriales con el objetivo de extraer crustáceos es insertado en una breve noticia cuyo título apunta a señalar las limitaciones que Brasil le impone al gobierno norteamericano, obligando a sus buques a abandonar sus aguas en diversas oportunidades. Cuestiones todas que daban solo algunos indicios del paisaje de violencia y conflicto social.

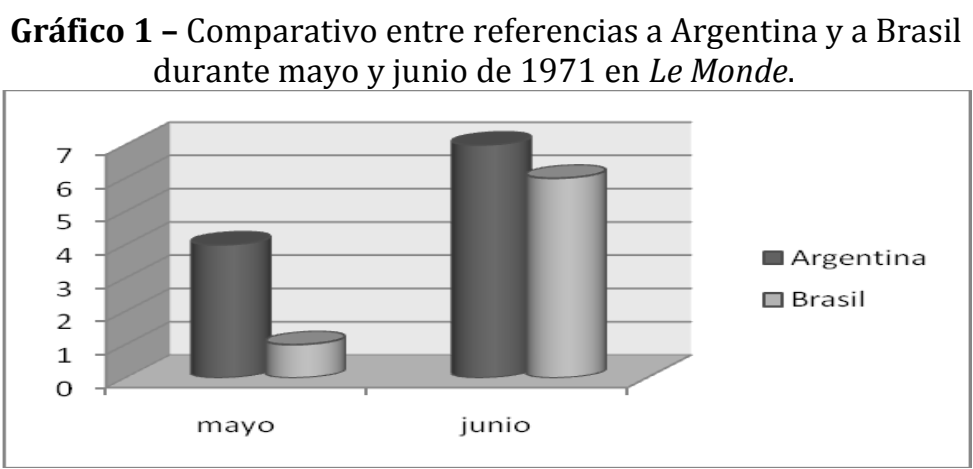

Fuente: elaboración propia. 
En 1972 la cantidad de noticias en Le Monde que refieren a Argentina asciende notablemente respecto del año anterior (ocho en octubre y diesicéis en noviembre), hecho relacionado directamente con el inminente retorno de Perón al país tras su extendido exilio. Ya en octubre la referencia principal respecto a Argentina apuntaba a las elecciones presidenciales de 1973, que serían por escrutinio directo. La información señala que, por medio del delegado de Perón en Argentina, el expresidente había propuesto al general Lanusse -considerando la desastrosa situación económica y social- un "programa de recostrucción nacional" para iniciar el camino hacia un gobierno democrático con participación de los militares, programa que en principio el gobierno acepta.

Entre tanto, la violencia en las calles se vuelve noticia en el diario francés: explosión fatal en el Hotel Sheraton de Buenos Aires, perpetrado por el comando peronista FAR, entre otros delitos contra miembros de las fuerzas armadas y sus domicilios, sumados a una ola de atentados con motivo de la conmemoración del 17 de octubre, "día de la lealtad peronista". Ese mismo día Perón anuncia su retorno al país. Tras el anuncio, el general Lanusse afirma que está dispuesto a tenderle la mano al ex presidente, pero que no aceptará el diálogo si la ofensiva peronista continua con los atentados. A los pocos días, Perón le pone fecha a una breve visita para mediados de noviembre. Así, Le Monde informa que viajará el 17 de noviembre en un vuelo especial de Alitalia hacia Buenos Aires, acompañado de 140 justicialistas a bordo. Al respecto, también recoje una declaración publicada por el diario La Razón de Argentina, en donde un comandante militar de alto rango dice que "[...] si Perón efectúa una misión de paz y desea concluir un acuerdo de conciliación nacional, podrá tener un diálogo abierto y público. Pero si es un factor de perturbación, deberá abandonar el país.” (LE GOUVERNEMENT ..., 1972).

El 9 de noviembre es la primera vez que Argentina aparece como noticia en tapa. Si bien se trata de un pequeño recuadro en la parte superior izquierda, el hecho informativo es el anuncio del retorno de Perón a su país. Luego, en la página cuatro de la misma edición esa información es ampliada con los detalles del regreso en el que se organizaría todo lo pertinente a las elecciones del año siguiente. Pero principalmente aborda la planificación para que tal retorno no fracase como el intento anterior en 1964. De allí en adelante durante noviembre, el peso informativo de la vuelta será reflejado en el significativo aumento de 
espacio que ocupará la cobertura del hecho noticioso. El acontecimiento es seguido en los días previos con detalle.

El 16 de noviembre, en una extensa nota central de tapa que continúa en el interior, Le Monde da cuenta de los pormenores de "la operación retorno" y ofrece detalles de las escalas y el horario de llegada a Ezeiza, pautado para las 11 horas de Argentina (15 horas en París) del viernes 17 de noviembre. También deja ver la preocupación nacional por el comportamiento tanto de los sindicalistas como de la juventud peronista en la espera del expresidente. El día del retorno, en la sección "Amériques", dedica la página entera a narrar la historia de "Perón y el pernonismo" -al que define como una mística nacional y popular-desde 1943 hasta 1955 e incluye un retrato de Evita, la ídola de los descamisados. Como dato lateral, cabe señal que las noticias que aparecen en esta página referidas a Argentina están firmadas por Charles Vanheche, periodista que también escribe para Opinão. De esta forma, aunque la relación entre ambos medios no haya sido públicamente declarada por Le Monde, el hecho de compartir un periodista los vincula y le otorga credibilidad a la publicación al presentarse como edición brasileña (POGGI, 2012).

El regreso de Perón a su país vuelve a ser tapa el 18 de noviembre y el objeto de la información está centrado en las medidas excepcionales de seguridad en Buenos Aires preventivas pero con la autorización de utilizar las armas en caso de disturbios- y en la expectativa y despliegue de la prensa para la transmisión en vivo del evento. Labreveux, el corresponsal en Argentina, cita a La Razón y Crónica (LE RETOUR..., 1972), diarios de la tarde, como fuentes que informan la reunión del ex presidente con el actual, pautada para el lunes siguiente en la casa de gobierno. En la misma página, el corresponsal del Le Monde en Madrid, Jose-Antonio Novais, da cuenta de la percepción que allí ha quedado acerca del famoso viaje: en una visita que no superará los siete días, Perón se esforzará en crear un movimiento de unidad nacional capáz de ser presentado en la escena política argentina como el frente cívico -de centro izquierda, con la participación de peronistas, demócrata cristianos y radicales discidentes- más importante de la historia y asegurarse de que se constituya en un auténtico movimiento nacional. A partir de aquí, la información sobre Argentina, si bien se mantiene constante, comienza a disminuir. La tensión, que había llegado a su punto máximo cuando 
aterrizó el avión que transportaba al exdictador aquel viernes 17 de noviembre, comenzó a disminuír con el transcurrir de los días.

Gráfico 2 - Comparativo entre referencias a Argentina y a Brasil durante octubre y noviembre de 1972 en Le Monde.

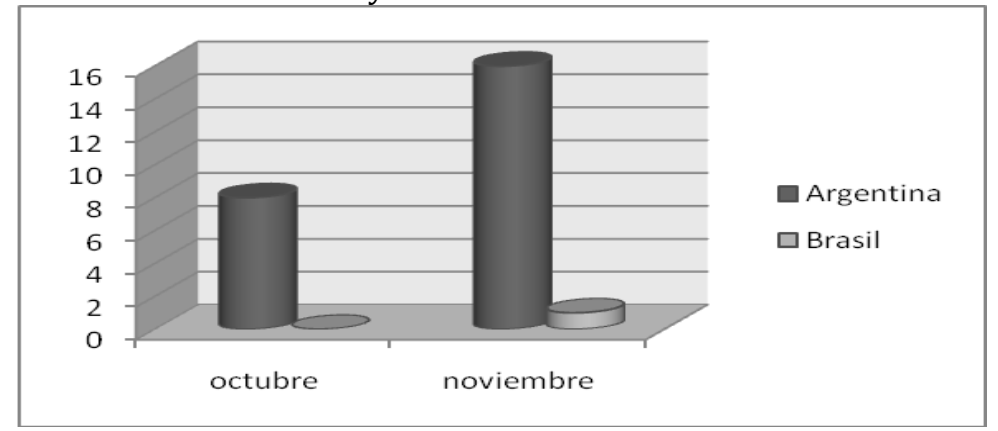

Fuente: elaboración propia.

Por último, en el mes de la fundación de Opinião, Brasil no es mencionado en Le Monde. Recién a principios de noviembre aparece la primera y única noticia al respecto, la cual aborda la ofensiva de las fuerzas armadas contra la guerrilla. Tal organización guerrillera estaba instalada en el Amazonia con el objetivo de dar marcha atrás a la dictadura, la que habría convertido al país "[...] en un vasto campo militar, donde no existe ley ni respeto por las personas." (L'ARMÉE..., 1972). Sin embargo, el gobierno procura desarmar las bases de la guerrilla mediante el lanzamiento de un operativo de acción cívica y social, que incluía distribución de medicamentos contra la lepra, la tuberculosis, la malaria, etc., y resolver algunos problemas relativos a la propiedad de la tierra.

Representar, en definitiva, es ordenar (ANGENOT, 2010). Y en ese orden se elige mostrar algunas cosas y ocultar otras. La intención del ocultamiento no necesariamente es esconder, pero el simple hecho de mostrar algunos hechos si y otros no les confiere importancia a algunos y se las quita a otros. Así, la jerarquía de los acontecimientos argentinos estuvo centrada principalmente, más que en las figuras políticas gobernantes, en el retorno de Perón al país luego de su largo exilio. Este acontecimiento fue retratado con todas sus controversias y fue una muestra fiel del intrincado mundo de la política argentina, de su desorganización y del vacío de poder que pocos años después se cristalizará en una atroz dictadura. En cambio Brasil, a pesar de estar viviendo uno de los momentos de mayor 
violencia en su historia, tuvo una escasa atención por parte de Le Monde, dando indicios de que en las representaciones mediáticas en tanto lo escandaloso se construye como importante y se elige mostrar, el silencio puede alterar la relevancia de un acontecimiento trágico y volverlo intrascendente.

\section{La caricatura como termómetro de la censura}

Incorporar actores en una escena discursiva plantea la necesidad de conformar una jerarquía, que hablará de quienes son los protagonistas y los eventos involucrados (FONTE, 2003). En este sentido, La Opinión retrató en sus tapas a los principales personajes de la historia nacional de la coyuntura de 1973, expuestos desde el ángulo más controvertido en cuanto a su actuación política. Este apartado contiene solo algunos ejemplos de la acción de la caricatura.

Uno de ellos es el del secretario general de la Confederación General del Trabajo (CGT) José Ignacio Rucci (JOSÉ..., 1973), en pleno conflicto de poderes y provocativas e insultantes declaraciones mediáticas con el secretario adjunto de la CGT Agustín Trosco, aparece en tapa como un caminante en actitud relajada que fuma un cigarrillo -posiblemente por la tranquilidad que le confería su inminente encuentro con Perón en Madrid- pero con sus manos hacia abajo, que acompañaban la acción de caminar en seña de "mano cornuta", una gestualidad popular italiana que indica la intención de alejar un mal del cuerpo (ver imagen 1)7 . Sin embargo, es sabido que sus lazos con Perón no fueron garantía para su futuro ya que en septiembre Rucci es asesinado en manos de Montoneros ${ }^{8}$.

Días después el periódico muestra a un Héctor Cámpora (candidato a presidente por el FREJULI, ante la imposibilidad de Perón a participar de los comicios) confrontativo, con los brazos alzados, ayudado por Vicente Solano Lima, su vice-presidente en la fórmula (CÁMPORA INICIÓ..., 1973). Esta actitud agresiva poco frecuente en el candidato, se resalta en relación al inicio de la campaña electoral en la que Cámpora pretende alejarse del lema popular "Cámpora al gobierno y Perón al poder" que lo estigmatizaba como marioneta de

\footnotetext{
7 Las fuentes de las imágenes se mostrarán en el texto donde se las citan.

${ }^{8}$ Montoneros fue una organización guerrillera que nació en 1970 para desestabilizar al gobierno autodenominado como "Revolución Argentina". De extracción izquierda-peronista, operó de manera armada y violenta. Su accionar se extendió hasta finales de la década, aunque tras la muerte de Perón fue declarado ilegal.
} 
hilos manejados por Perón. El objetivo que subyace la representación es la intención del candidato de posicionarse como claro representante nacional del movimiento justicialista (ver imagen 2).

Imagen 1 - José Ignacio Rucci.

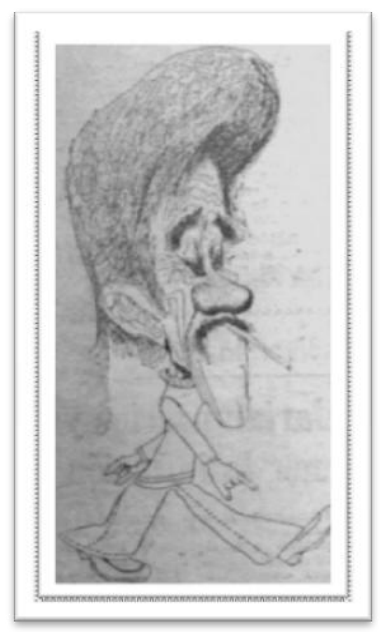

Imagen 2 - Héctor Cámpora y Vicente Solano Lima.

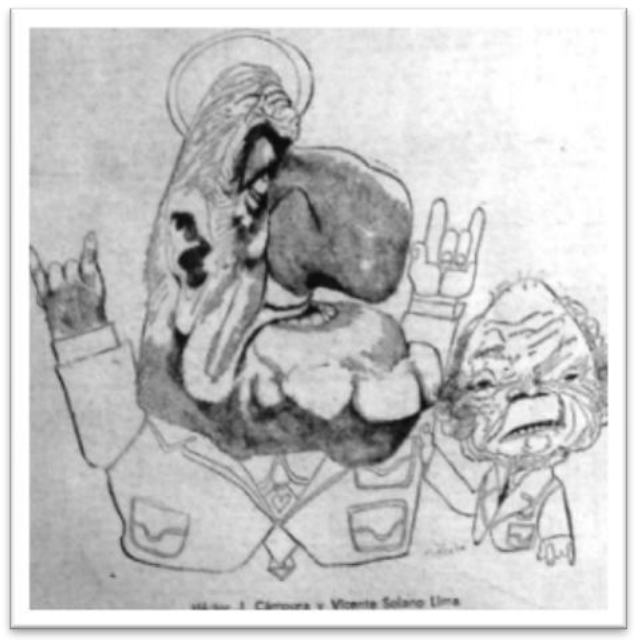

Otro ejemplo puede observarse, en medio de este clima optimista de retorno a la democracia, en una caricatura de una bomba que desciende aceleradamente con la cara de Perón justamente el día de la renuncia de Cámpora al cargo presidencial. El convocante líder irrumpe en la escena política como una bomba sonriente bajo el título que anuncia: “Renuncian hoy Campora-Lima para trasferir el poder a Perón-Balbín.” (LA OPINIÓN, 1973). Esta vez la imagen corresponde a la interpretación del fenómeno "Perón al poder" expresada por el dibujante Raanan Laurie del New York Times, cuyos derechos adquirió La Opinión en exclusividad ((LA OPINIÓN, 1973) (ver imagen 3). En dicha sonrisa queda evidenciado ante el mundo entero que el objetivo de los comicios siempre había sido el retorno, aunque explosivo, y la candidatura de Cámpora componía una pieza más de la planificada estrategia para el regreso hacia Argentina. Esta caricatura será la última en aparecer en la portada del semanario. La siguiente imagen corresponderá a una fotografía -la primera en tapa en la historia del medio- del designado presidente tras el golpe de Estado de 1976, General Jorge Rafael Videla (EL GENERAL..., 1976) (ver imagen 4). 
Imagen 3 - Juan Domingo Perón.

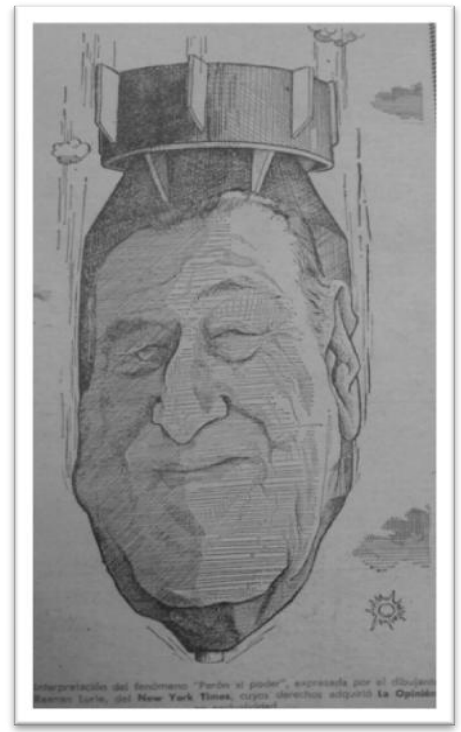

Imagen 4 - Gral. Videla.

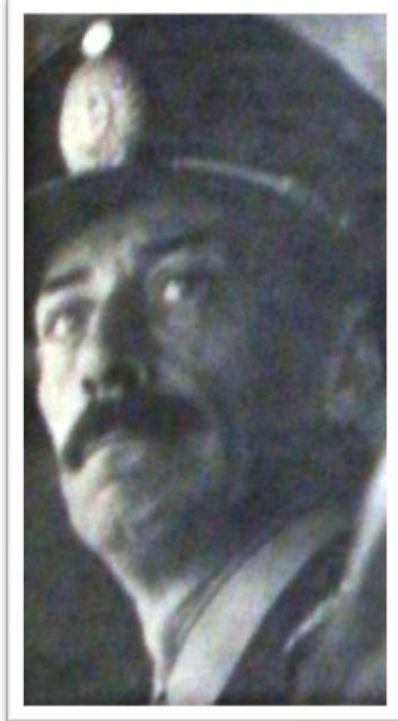

En cuanto al país vecino, además de las cuestiones relacionadas a las negociaciones por el precio del trigo y a la disputa del Paraná por los recursos hídricos (que también incluían a Paraguay), el periódico no hizo foco en la problemática brasileña. Al respecto, solo se publicó una vez una breve historieta, extraída del Jornal do Brasil, que representaba de forma muy sencilla las relaciones diplomáticas entre ambos países (MC LOUGHLIN y Barboza..., 1973).

En cambio, durante 1973 el semanario Opinião comporta diferencias significativas respecto del caso argentino. En primer lugar, el formato semanal le permitía concentrar el foco de la atención en algún tema que pretendía destacar, pero que tenía cierta prolongación en el tiempo en cuanto a su desarrollo. Es decir, no atendía solo a lo cotidiano, sino que se podía dimensionar su importancia al menos en una perspectiva semanal de permanencia en la agenda pública. Si bien la caricatura se inició con su número 0 en adelante predominó el dibujo, aunque también estuvo muy presente la composición de imágenes (foto y dibujo) con sentido irónico y por supuesto la caricatura que, aparentemente, estaba reservada para momentos claves en donde la imagen necesitaba trascender la textualidad. Ante la escalada de censura ocurrida durante 1973, las oportunidades de expresión se redujeron principalmente en la caricatura, que era revisada con lupa por el tono burlón e irónico intrínseco del estilo. Así, prevalecieron las composiciones gráficas que permitían camuflar y a la vez sugerir algo de 
la ironía y la resistencia que el semanario pretendía expresar. Las caricaturas volvían vedadas y eran repetidos los espacios en negro con la leyenda "leia e assine Opinião": el contrasentido radicaba en la leyenda de "leer y opinar" sobre el negro que representaba la censura de la opinión.

Así, los protagonistas de la escena local, principalmente Medici y su sucesor Geisel, eran presentados en formales dibujos, en los que la acentuación de la gestualidad o algún rasgo de la composición artística deslizaban muy sutilmente, con la intención de eludir a la censura, algo de la postura opositora y de resistencia que el semanario asumía. Por ejemplo, en el segundo número del año aparece un Medici partido al medio, mitad en negativo y mitad con una sombra por detrás, bajo el titular: "Médici e suas estatísticas de fim de ano. A POESÍA ACABOU"9 (ver imagen 5). Otro ejemplo se advierte hacia junio, cuando Opinião presenta una imagen de Ernesto Geisel. El dibujo, levemente caricaturizado, muestra sobre un fondo oscuro una cara con arrugas bien pronunciadas y mucosidad saliente de las fosas nasales, una imagen sórdida e imponente que tal vez ha sido el límite permitido para mostrar por la censura (0 PRONUNCIAMENTO..., 1973) (ver imagen 6).

Imagen 5 - Emílio Garrastazu Médici.

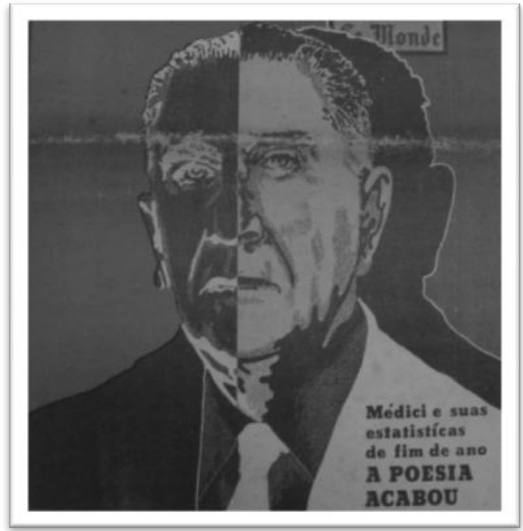

Imagen 6 - Ernesto Geisel.

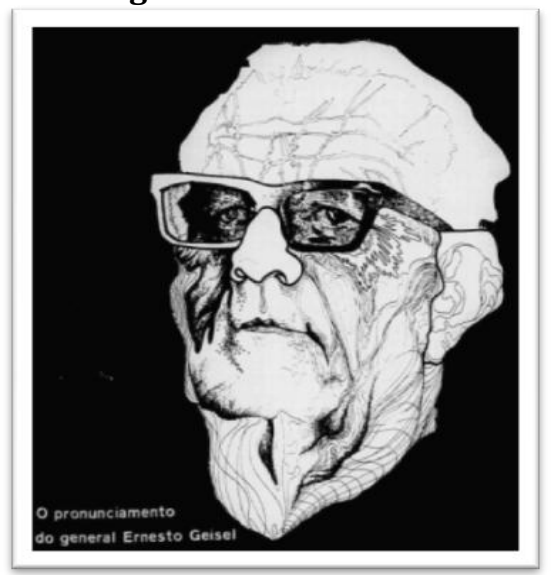

En cambio, las caricaturas propiamente estuvieron reservadas para actores políticos destacados del escenario mundial. El protagonista fue el presidente de Estados Unidos, Richard Nixon, quién apareció desfigurado, con sus ropas manchadas con manos negras

9 Las mayúsculas pertenecen al semanario (OPINIÃO, 1973). 
(A POLÍTICA..., 1973) (ver imagen 7), en referencia al famoso escándalo norteamericano conocido como "Watergate". Por último, cabe señalar la presencia de uno de los protagonistas de la escena argentina en el semanario: en el contexto de las elecciones presidenciales, el rostro de Cámpora se muestra caricaturizado en blanco y negro, aunque solo acentuando sus rasgos faciales, sobre una bandera argentina a color (CÁMPORA NO..., 1973) (ver imagen 8). Sumado a las representaciones caricaturizadas de Nixon, se deduce que la broma se permitía cuando los actores burlados no eran locales.

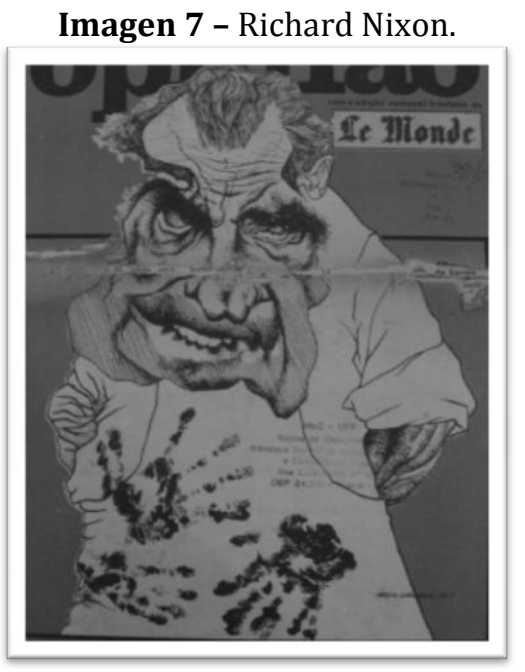

Imagen 8 - Héctor Cámpora.

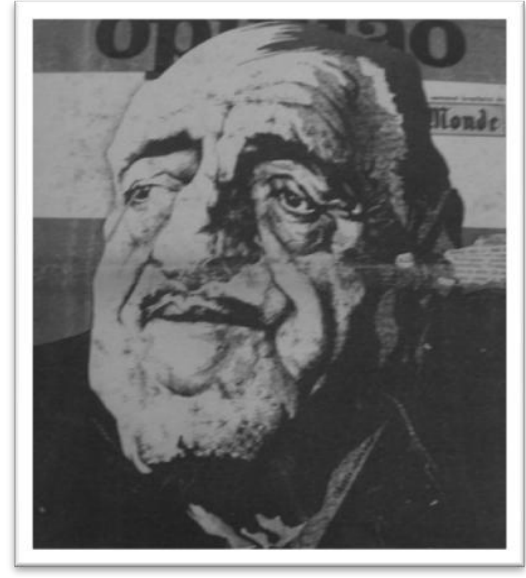

Si bien, en Opinião, la caricatura fue escueta en 1973, ya que predominaba la composición fotográfica, es notable la postura combativa por medio de la representación gráfica irónica. Ese contexto represivo que no le permitió expresarse libremente quedó plasmado en los recuadros negros que evidenciaban la censura y en la búsqueda por burlar los censores con la intención de dejar a la vista una realidad oscura que pedía a gritos ser modificada.

\section{La escena enunciativa de la reforma agraria}

Si bien el debate de la propiedad de la tierra en la actualidad se encuentra atravesado por la perspectiva de la noción de suelo como recurso natural (REBASA; CARBAJALES, 2012) y atienden también a cuestiones humanitarias sobre el desalojo en masa de personas 
(CÁMPORA, 2012), en la década de 1970 las discusiones no alcanzaban tales aristas, y en tanto cuestión agraria, la discusión estaba centrada en la tenencia y en la productividad.

En cuanto a la problemática de la propiedad agraria, ni en Argentina ni en Brasil han ocurrido cambios irreversibles de tipo "revolucionario" en sus sistemas de tenencia de la tierra. Tanto sus estructuras agrarias, lo mismo que sus reacciones ante los problemas agrarios, pueden considerarse representativos de la situación Latinoamericana del período estudiado (BARRACLOUGH; DOMIKE, 1970). Además, la política de tierras era revisada a nivel mundial desde la década de 1960, y la idea de una reforma agraria aparecía como una amenaza para los sectores latifundistas latinoamericanos, y por lo tanto cualquier política que intentara modificar el modo de tenencia de la tierra se volvía conflictiva y encontraba resistencias.

Las políticas agrarias proyectadas que regularían el uso y la tenencia de la tierra en Argentina se inscriben dentro del paquete de medidas consideradas por los sectores terratenientes como reformistas, y en ese sentido fueron entendidas por tales sectores como un atentado al derecho constitucional de propiedad privada. La idea rectora estaba basada en que la tierra debía ser un bien de producción y no un bien de renta y especulación. Estos planteos, contenidos en la plataforma electoral de 1973, fueron denominados como "Reforma Agraria Integral" y profundizados en las Pautas Programáticas para el Gobierno Justicialista de la Reconstrucción Nacional, donde se ratificaba el principio de que la tierra debe ser para quien la trabaja, alentando al acceso de los productores a la propiedad y a la erradicación de los latifundios y los minifundios improductivos.

En Brasil, la cuestión de la reforma agraria había sido colocada con fuerza en la escena nacional a inicios de la década de 1960, gracias a la intensa movilización de los trabajadores rurales asalariados y pequeños productores (PAULA; STARLING; GUIMARÃES, 2006). Si bien el régimen militar en un principio sostuvo la política reformista del gobierno derrocado, hacia 1970 fue dejando de lado las intenciones de reformar el campo para concentrarse en proyectos de colonización y agronegocios. En 1970 el Instituto Brasilero de Reforma Agraria (IBRA) creado por el Estatuto de la Tierra para gestionar su distribución, fue rebautizado como Instituto de Colonización y Reforma Agraria (INCRA), nomenclatura que da cuenta de las nuevas preocupaciones del gobierno militar (SÁ MOTTA, 2006). En la actualidad, el INCRA 
continúa en funciones y ha avanzado en sus regulaciones hacia las limitaciones a extranjeros para la adquisición de tierras agrícolas con fines de uso vinculado a la actividad, pero de todas formas los proyectos deben ser aprobados por el Ministerio de Agricultura (CÁMPORA, 2012).

En el diario La Opinión es posible diferenciar voces propias y ajenas, y la intencionalidad de incorporar una u otra de las voces opera en función de construir un efecto de sentido determinado. Esta diferenciación de se encuentra marcada en el contraste de las notas que llevan la firma del periodista donde se incorporan citas textuales y enunciados referidos con las que no llevan firma, donde queda reflejado el propio discurso del diario. ${ }^{10}$

La expresión reforma agraria aparece constantemente asociada a otros términos que orientan la dirección de la representación que construirá el medio, por ejemplo: debate, estudio, impuesto a la tierra, búsqueda de una reforma pacífica y ordenada, eliminación de latifundios, criterios superadores en cuanto a productividad y minifundios. Es el caso de en una nota publicada el 17 de mayo de 1973 (ESTUDIAN..., 1973), donde el concepto de reforma agraria se vincula con los de debate y estudio, además de incluir en el concepto de reforma como una afirmación- al impuesto a la tierra. En el cuerpo de la noticia se argumenta que "[...] el impuesto a la tierra es componente fundamental de cualquier reforma agraria." (ESTUDIAN..., 1973).

Luego, el $1^{\mathrm{o}}$ de julio, y relacionado con el debate parlamentario en torno a las reformas económicas, se expresa que:

Más evidentes son las influencias ejercidas en contra de la ley que establece el impuesto a la renta normal potencial de la tierra. Algunos legisladores plantean una reforma agraria total mediante la expropiación de las tierras, cuando el proyecto consiste en realidad en una reforma agraria en sí mismo, pues obligará a los terratenientes, por el enorme peso de la carga impositiva que deberán afrontar, a deshacerse de las extensiones que no produzcan o conserven a título especulativo. Las entidades ruralistas se han puesto unánimemente en contra del proyecto, aún aquellas que por su extracción deberían acompañar esta medida de avanzada, y exigen que el impuesto a la renta potencial no sea tomado como anticipo de réditos, con lo cual disminuiría grandemente su progresividad y su efecto redistribuidor. (DESDE..., 1973, p. 12).

\footnotetext{
${ }^{10}$ Es posible definir la postura que La Opinión asume en relación a una posible reforma agraria, entendiendo que las noticias que no poseen firma y que tampoco incorporan un discurso ajeno, en los términos en que Voloshinov lo propone, o que no añaden intertextualidad manifiesta (en términos de Fairclough, 1992), serían las que se acercan a definir la postura ideológica, operando como línea editorial.
} 
La noticia apunta a establecer un espacio conciliador de posturas extremas que intentan influir en la política agraria, tanto de parte de quienes se oponen rotundamente al IRNP (llamando la atención a las entidades ruralistas como la Federación Agraria Argentina, que por sus reclamos históricos debería apoyar esta ley) como a quienes plantean una reforma agraria total (señalando que el propio proyecto consiste en una reforma agraria en sí mismo). La tendencia de La Opinión tiende a sostener la política económica propuesta por el gobierno.

En cuanto a las notas firmadas, las referencias más significativas focalizan en la región pampeana: incorporan la opinión de un experto que cuestiona la política agrícola en América Latina u ofrecen el testimonio de un especialista que explica la crisis del concepto de reforma agraria. Así, las características retóricas más de explicación que de opinión, se utilizan a fin de intensificar una función didáctica respecto de la conveniencia e importancia de repartir con criterio la renta de los impuestos aplicados y realizar cambios en la tenencia de la tierra.

De esta manera, las voces que predominan son construidas por figuras de autoridad en la materia y sus predicaciones, incluidas en un contexto de estilo de prensa analítico, tienden a moderar el impacto a priori que podría causar la idea de una reforma en la propiedad. Las alocuciones que aparecen directamente relacionadas con una reforma agraria en las notas en donde prima la voz de un experto son: 1) dudas sobre la efectividad de una reforma basada en el reparto igualitario de tierras; 2) cuestionamiento a las formas clásicas de reforma; 3) reforma del régimen impositivo agrario; 4) apoyo de la burguesía urbana al proceso de reforma, en busca del debilitamiento de terratenientes y de condiciones económicas favorables; 5) proceso.

En cuanto a los fundamentos expresados por la dirigencia política, se condicen con las estructuras argumentativas elaboradas desde La Opinión, las cuales operaron del siguiente modo:

a) se presentaron los argumentos expuestos por la dirigencia política; 
b) los argumentos considerados como línea editorial ${ }^{11}$ (aparecían en notas sin firma) coincidían con los dichos del gobierno;

c) se publicaron notas firmadas por expertos en la temática agraria que coincidían y reforzaban los argumentos desde esta postura de especialista;

d) se citaron argumentos de posturas ideológicas de izquierda, que además coincidían con la postura y la propuesta oficial;

e) los argumentos disconformes con la política oficial tuvieron una aparición limitada respecto a la temática abordada y aparecieron atenuados.

En Opinião las noticias relacionadas con una reforma agraria se pueden separar en tres grupos: las que mencionan el panorama agrario nacional, las que mencionan al panorama agrario mundial y las que mencionan la política agraria argentina.

En relación al primer grupo, las noticias aparecen desde inicios de febrero bajo el interrogante que cuestiona si finalmente se había iniciado una reforma, en correspondencia con la política de tierras planteado por el INCRA y la ejecución de PROTERRA. ${ }^{12}$ En una misma página, el semanario publica tres notas: en la primera de ellas plantea el interrogante mencionado mediante el recurso de inserción recurrente de discursos citados, en donde funcionarios del INCRA señalan la propuesta como una política sabia con acuerdo de empresarios y propietarios, pero la nota termina predicando que el futuro de la reforma es un misterio (FINALMENTE..., 1973). La segunda, contextualiza la problemática como un tema discutido por todos los gobiernos de la revolución (IBRA..., 1973). La última, aporta la opinión de un experto en reformas agrarias latinoamericanas, Pompeu Accioly Borges, quién actúa como enunciador en la escena y detalla las características fundamentales que debe contener una reforma, entre las que se destacan que: debe ser un proceso masivo, rápido y drástico de redistribución de derechos sobre las tierras; debe movilizar las fuerzas políticas y entidades

\footnotetext{
${ }^{11}$ Para Timerman, redactar un editorial como tal no tenía sentido. Consideraba que el diario entero debía ser entendido como una expresión de opinión: "No le encontraba sentido a una editorial. Si hacíamos todo un diario, ¿qué más? Ahí estaba todo lo que queríamos decir y, como eran tan solemnes los editoriales de todos los diarios, la gente no los leía. ¿Qué voy a decir en una editorial si está todo en el diario? En mi diario todo expresaba opinión. Un dibujo de Sabat tenía opinión. Ésa es la identidad del diario. La identidad del diario está en el diario y no en los editoriales que escribe un señor sentado en una silla y mirando diccionarios." (RUIZ, 2001, p. 42-43).

12 Programa de Redistribuição de Terras e Estímulo à Agroindústria do Norte e Nordeste.
} 
representativas de la población rural; debe adoptar un sistema económico de inversión; debe ser parte integral de un plan de desarrollo económico (COMO EVITAR..., 1973).

Luego, en la última edición de julio, aparece una crónica en relación a la propuesta del INCRA para atraer a la región amazónica a la iniciativa privada. En relación a ello, la postura del semanario es crítica, y la estrategia que utiliza es la intensificación de los argumentos negativos, ubicados en la conclusión de la nota:

E frequentemente uma carta denuncia detalhes insuspeitados, como a que Antonio Apolonio de Moura enviou, há dois meses, a seu compadre Mazinho, o deputado federal José Vieira Filho (ARENA-CE): Compadre: eu mando lhe dizer que aqui não se vê nada do que é prometido como eles dizem por aí. (INCENTIVANDO..., 1973, p. 6).

La siguiente noticia aparece en septiembre y su tema central gira en torno a la posible expulsión de ocupantes de tierras del municipio de São Domingos de Capim (AS TERRAS..., 1973). En este mismo sentido, hacia fin de mes otra nota refleja la resistencia armada en Maranhão ante el posible desalojo de tierras, y explica la problemática de los minifundios en la región (AS TERRAS DISPUTADAS, 1973).

Por último, en el marco de la información que aborda la cuestión de la agricultura brasileña, también es posible encontrar referencias a la modalidad de tenencia de la tierra, y observa que sería necesaria“[...] a reformulação da política agrícola do país, adequando-a ao desenvolvimento da economía no seu todo, sem o que graves problemas serão gerados pelas desigualdades de renda interregionais" (UM SETOR..., 1973, p. 6).

En la misma edición y en la página siguiente de la noticia recién mencionada, Chico de Oliveira, sociólogo y uno de los más reconocidos intelectuales brasileros de izquierda además de activista del PSTU (Partido Socialista de los Trabajadores Unificado), realiza un análisis de la división y de la concentración de la tierra en Brasil. Cuestiona la política oficial que, a partir de esquemas teóricos de la economía neoclásica, considera a la agricultura como un espacio donde los factores económicos son libres y móviles, pero asume que el crecimiento, aunque lento, es siempre constante y que el tiempo determinará el momento de correr (O QUE..., 1973).

En el segundo grupo de noticias mencionado, las que giran en torno a la problemática de la tierra a nivel mundial, se registran tres: la primera, publicada en abril y firmada por 
Charles Vanheche, analiza el fracaso de la reforma Colombiana, frenada por el propio gobierno entre enero de 1970 y marzo de 1972, reforma que había sido lanzada en 1961, y hasta 1972 solo se habían expropiado 700 hectáreas. Si bien aparece firmada, la estructura es ganada por citas textuales de diferentes actores colombianos que habían desarrollado el proyecto (COL^MBIA..., 1973). La segunda nota analiza la industrialización del campo en Bulgaria, dividida a partir de 1970 en 172 unidades agroindustriales gigantes - enfatizando en la especialización, la mecanización y la centralización - cuya oposición a la reforma agrícola se localizó en los jefes provinciales del partido comunista, quienes sostenían que su poder sería diluido ante la presencia de técnicos, ingenieros y administradores agrícolas subordinados a los ministerios centrales. La conclusión expresa a la vez escepticismo y admiración hacia el funcionamiento de unidades agrícolas tan grandes, pero sostiene que el costo de ese tipo de agricultura sería muy alto en función de la cantidad de personas necesarias para mantener su buen funcionamiento (A INDUSTRIALIZAÇÃO..., 1973). En este grupo también es posible ubicar una conmemoración realizada en diciembre por Opinião en los 25 años del éxodo palestino, ya que en la nota resalta su situación, desde entonces, de "sin tierra" (25 ANOS..., 1973).

Por último, en el grupo de noticias caracterizado por las que mencionan la política agraria argentina, el primer registro data de marzo, cuando el semanario realiza una referencia al debate en términos de reformista y como consecuencia de la intención de reinstalar un gobierno populista (O QUE HÁ DE NOVO..., 1973). En este mismo sentido en julio, en un análisis de los días de Héctor Cámpora en el gobierno, reproduce el reclamo de grupos revolucionarios opositores al gobierno (FAR - ERP), quienes consideraban que las reformas también deberían afectar los intereses de los monopolios y las oligarquías (OS CINQUENTA..., 1973). Finalmente, en noviembre menciona nuevamente la tipología de políticas reformistas adoptadas por el gobierno peronista, acentuando que la oligarquía rural se vería perjudicado por un aumento del $75 \%$ en el impuesto a la Renta Normal Potencial de la Tierra, el cual entraría en vigencia recién en 1975.

Luego de realizar este recorrido por las noticias publicadas en Opinião que mencionan la problemática agraria, se puede establecer que: en el primer grupo, la intencionalidad se encuentra orientada a cuestionar la efectividad de la política de tierras ya implementada en el 
país. En el segundo grupo, el análisis está ajustado a momentos históricos que no interfieren significativamente con la situación actual. Las noticias que integran el último grupo pueden ser clasificadas como crónicas informativas, y las breves referencias a las políticas de tierras argentinas no poseen estrategias enunciativas específicas que busquen crear un efecto de sentido respecto de una posible reforma agraria.

\section{Conclusiones}

Si bien La Opinión y Opinião nacen mirando al mismo modelo, la coyuntura de cada uno de los países en que ambos medios se desarrollan determina que tengan un rol político diferenciado. Así, mientras que La Opinión se inicia en un período argentino democrático, con la intención de conformar un espacio analítico de las noticias diarias, Opinião nace con la intención de convertirse en un espacio de análisis, pero contestatario hacia un gobierno militar que comienza a perder su fuerza.

La Opinión encarnó para la prensa argentina un nuevo modelo de periodismo que resulta emblemático hasta la actualidad. El carácter analítico y las notas firmadas daban cuenta de un período de libertad del que gozó la prensa a principios de la década de 1970 en el contexto del retorno del peronismo al poder, libertad que se extinguió rápidamente en la mitad de la década. Sin embargo, en tanto la prensa obtenía nuevos espacios de libertad, en el ámbito político comenzaba a gestarse uno de los momentos de violencia más críticos de Argentina. Y en este sentido, el diario fue tan fluctuante como el período político.

En cuanto a Opinião, la actividad llevada a cabo se mantuvo acorde a la línea editorial definida por su origen contestatario. En relación a la representación de sus máximos líderes políticos, y a diferencia de La Opinión, la postura asumida no fue condescendiente con el gobierno y, muy cautelosamente, utilizó el espacio para cuestionar la política en general.

A partir de la utilización de la caricatura es posible determinar que, si bien estéticamente se encuentran similitudes notables, estos medios fueron concebidos con objetivos distintos, y consecuentemente también fueron diferentes los resultados obtenidos. Así, mientras que La Opinión se desenvolvía en un espacio de aparente libertad de expresión, por detrás se gestaba el relato argentino más nefasto. Al mismo tiempo, en un ámbito de 
marcada censura a la prensa, el semanario Opinião peleaba por echar luz a esa situación y se consagraba como uno de los espacios de resistencia en contra del régimen militar.

En relación a la cuestión de la propiedad de la tierra, cabe mencionar que aunque el estilo periodístico de esta prensa de análisis no contemplaba específicamente la cobertura del agro, la temática estuvo presente y se hizo eco de los posicionamientos discursivos de cada uno de los periódicos, y representó las repercusiones y los debates que al respecto se instalaron en la sociedad.

Por último, cabe mencionar que las estrategias argumentativas de La Opinión que procuraban apoyar a la política del gobierno de Cámpora, sostenidas durante el gobierno de Perón, cambiarán sustancialmente tras el fallecimiento del líder justicialista, específicamente a partir del cambio del gabinete económico realizado por M. E. Martínez de Perón en su función como presidente. De este modo, mientras Opinião profundiza en las fisuras de un gobierno militar para abrirle camino a la democracia, a lo largo de su breve existencia $L a$ Opinión realiza cambios significativos en sus estructuras argumentativas propiciando de algún modo desde sus páginas el pasaje de la democracia hacia la dictadura militar.

\section{Bibliografía}

25 ANOS sem terra. Opinião, Rio de Janeiro, p. 13, 21 dez. 1973.

ANGENOT, Marc. El discurso social: los límites históricos de lo pensable y lo decible. Buenos Aires: Siglo XXI, 2010.

A INDUSTRIALIZAÇÃO do campo. Opinião, Rio de Janeiro, p. 17, 30 jul. a 7 ago. 1973.

A POLÍTICA dos cowboys: um documento sobre as origens de WATERGATE. Opinião, Rio de Janeiro, 7 al 14 mayo 1973.

AS TERRAS DISPUTADAS. Opinião, Rio de Janeiro, p. 4, 24 set. a 1 out. 1973.

AS TERRAS em disputa. Opinião, Rio de Janeiro, p. 4, 3 al 10 sep. 1973.

BARRACLOUGH, Solon; DOMIKE, Arthur. La estructura agraria en siete países de América Latina. En: FLORES, Edmundo et al (Org.). Reformas agrarias en América Latina. Buenos Aires: Juárez, 1970. p. 115-220. 
BETHELL, Leslie. Historia de América Latina: política y sociedad desde 1930, Tomo 12. Cambridge: Editorial Crítica, 1997.

BRIGGS, Asa. Las ciudades del siglo 20. En: BRIGGS, Asa. Historia mundial del siglo XX. España: Ramos Cortes, 1972.

BRIGGS, Asa; CLAVIN, Patricia. Historia contemporánea de Europa: 1789-1989. Barcelona: Crítica, 1997.

CÁMPORA, Mario. Notas sobre leyes de tierras en el derecho comparado. Derecho Público, Buenos Aires, v. 1, n. 1, p. 81-99, mayo 2012.

CÁMPORA INICIÓ en el Frente la discusión sobre pautas programáticas de gobierno. La Opinión, Cúcuta, 21 Ene. 1973a.

CÁMPORA NO gobernó. Opinião, Rio de Janeiro, 28 maio a 4 jun. 1973.

COMO EVITAR a reforma. Opinião, Rio de Janeiro, p. 7, 5 a 12 fev. 1973.

COLÔMBIA: uma reforma agrária sem êxito. Opinião, Rio de Janeiro, p. 13, 9 a 14 abr. 1973.

DESDE la izquierda y la derecha se ejerce una acción de pinzas contra los proyectos. La Opinión, Cúcuta, p. 12, 1 jul. 1973.

EL GENERAL Videla fue designado presidente. La Opinión, Cúcuta, 27 mar. 1976.

ESTUDIAN 93 entidades el impuesto a la tierra. La Opinión, Cúcuta, p. 13, 17 mayo 1973.

FAIRCLOUGH, Norman. Discourse and social change. Cambridge: Polity Press, 1992.

FERNANDO GASPARIN: publisher and industrialist. Independent, London, 25 Oct. 2006. Obituaries. Disponible em: <http://www.independent.co.uk/news/obituaries/fernandogasparian-421600.html>. Acceso en: 27 mar. 2013.

FINALMENTE a reforma? La Opinión, Cúcuta, p. 7, 5 a 12 feb. 1973.

FONTE, Irene. La escena enunciativa en la prensa. En: BERARDI, Leda (Org.). Análisis crítico del discurso: perspectivas latinoamericanas. México: Frasis, 2003. p. 65-84.

PAULA, Delsy Gonçalves de; STARLING, Heloísa Maria Murgel; GUIMARÃES, Juarez Rocha (Org.). Sentimento de reforma agrária, sentimento de república. Belo Horizonte: UFMG, 2006.

HOBSBAWN, Eric. Historia del siglo XX. Buenos Aires: Crítica, 1998. 
IBRA, INDA, INCRA, PROTERRA. Opinião, Rio de Janeiro, p. 7, 5 a 12 feb. 1973.

IGLÉSIAS, Francisco. Breve Historia contemporánea del Brasil. México: FCE, 1994.

INCENTIVANDO a ocupação da Amazônia. Opinião, Rio de Janeiro, p. 6, 30 jul. al 7 ago. 1973.

JOHNSON, Douglas. Poder y caída del general De Gaulle. En: TAYLOR, A. J. P.; ROBERTS, J. M.;

Historia mundial del siglo XX. v. 5. Barcelona: Vergara, 1972. p. 403-406.

JOSÉ Rucci viajó a Madrid con informes para Perón. La Opinión, Cúcuta 18 Ene. 1973.

L'ARMÉE aurait engagé une action contre des guerrilleros en Amazonie. Le Monde, Paris, p. 64 nov. 1972.

LA OPINIÓN, Cúcuta, 13 junio 1973.

LE GOUVERNEMENT autorise le retour de Perón le 17 novembre prochain. Le Monde, Paris, p. 2, 28 Oct. 1972.

LE RETOUR de sécuritñe exceptionnelles ont été prises à Buenos Aires. Le Monde, Paris, tapa, 18 nov. 1972.

MC LOUGHLIN y Barboza habrían convenido una tregua en el conflicto del Paraná. La Opinión, Cúcuta, 8 abr. 1973.

MOCHKOFSKY, Graciela. Timerman. Buenos Aires: Sudamericana Debolsillo, 2004.

O PRONUNCIAMENTO do general Ernesto Geisel. Opinião, Rio de Janeiro, 16 a 23 jul. 1973.

OPINIÃO, Rio de Janeiro, 1 a 8 janeiro 1973.

OPINIÃO: um novo semanário nacional. Rio de Janeiro: 23 out. 1972-8 abr. 1977.

O QUE HÁ DE NOVO no peronismo? Opinião, Rio de Janeiro, p. 11, 19 al 26 mar. 1973.

O QUE É a agricultura brasileira? Opinião, Rio de Janeiro, p. 7, 10 dez. 1973.

OS CINQUENTA dias de Hector Campora. Opinião, Rio de Janeiro, p. 16, 30 jul. a 7 ago. 1973.

POGGI, Marina. Problemática agraria y prensa escrita en la argentina de los años 70: representaciones y debates sobre la propiedad de la tierra. Munich: GRIN, 2012.

RAFFIN, Marcelo. La experiencia del horror: subjetividad y derechos humanos en las dictaduras y posdictaduras del Cono Sur de América. Buenos Aires: Editores del Puerto, 2006. 
RAITER, Alejandro; ZULLO, Julia. La caja de Pandora: la representación del mudo en los medios. Buenos Aires: La Crujía, 2008.

RAPOPORT, Mario. Historia económica, política y social de la Argentina (1880-2003). Buenos Aires: Ariel, 2005.

REBASA, Marcos; CARBAJALES, Juan. La noción del suelo como recurso natural: conceptualización constitucional y usos posibles. Derecho Público, Buenos Aires, v. 1, n. 1, p. 57-79, mayo 2012.

ROST, Alejandro. Periodismo de explicación. Red-acción, General Roca, 2003. Disponible en: $<$ http://red-accion.uncoma.edu.ar/asignaturas/periodismoexplicacion.htm>. Acceso en: 12 feb. 2013.

RUIZ, Fernando. Las palabras son acciones: historia política y profesional de La Opinión de Jacobo Timerman (1971-1977). Buenos Aaires: Perfil Libros, 2001.

SÁ MOTTA, Rodrigo Patto. Do outro lado da cerca: os conservadores e a reforma agrária. In: GUIMARÃES, Juarez Rocha; PAULA, Delsy Gonçalves de; STARLING, Heloisa Maria Murgel (Org.). Sentimento de reforma agrária, sentimento de república. Belo Horizonte: UFMG, 2006.

UM SETOR em expectativa. Opinião, Rio de Janeiro, p. 6, 10 dez. 1973.

VERÓN, Eliseo. Fragmentos de un tejido. Barcelona: Gedisa, 2004.

WODAK, Ruth. Métodos del Análisis Crítico del Discurso. Barcelona: Gedisa, 2003.

\section{Estratégias e representações em tempos de censura: os casos da La Opinión (Argentina) e Opinião (Brasil)}

\section{Resumo}

A “imprensa de análise" se consolida na América Latina na década de 70 com o jornal La Opinión (Argentina, 1971) e a Opinião semanal (Brasil, 1972) num contexto de restrição à liberdade de expressão. As novidades foram as colunas assinadas, a falta de espaço editorial, a priorização da análise de alguns tópicos em vez do fornecimento de uma variedade de informações atuais e o foco nas minorias com interesses particulares. A marca que caracteriza ambos os meios residia na utilização de caricaturas e composição de imagens de sentido irônico como uma estratégia para expressar o que não pode ser colocado em texto. Contemplando 
tais semelhanças, a proposta é estudar o desempenho da imprensa em seu papel de ator político no início de um período de censura que vai deixar a sua marca na história da democracia latino-americana.

\title{
Palavras-chave
}

Análise de imprensa. Representação. Discursos.

\section{Strategies and representations in times of censorship: the cases of La Opinión (Argentina) and Opinião (Brazil)}

\begin{abstract}
The "analytic press" consolidates itself in Latin America in the 70's with the newspaper La Opinión (Argentina, 1971) and the weekly Opinião (Brazil, 1972) in a context of restricted freedom of expression. The innovations were that columns started being signed, there was no editorial space, priority was given to the analysis of a few topics rather than to a variety of information and it was focused on minorities with particular interests. The hallmark that characterized both media vehicles laid in the use of cartoons and image compositions with ironic sense as a strategy to express what could not be put into text. Contemplating such similarities, the proposal is to study the performance of the press in its role of a political actor at the dawn of a censorship period that will leave its mark in the history of Latin American democracy.
\end{abstract}

\section{Keywords}

Press Analysis. Representations. Discourse.

Recebido em 03/08/2015

Aceito em 17/08/2015 